\title{
Sibcatie gowreal
}

Jurnal Ilmiah Bidang Sosial, Tkonomi, Budaya, Tekuologi, dan Pendidikan

E-ISSN: 2809-8544

\section{A TRANSITIVITY ANALYSIS ON THE THIRD SEMESTER ENGLISH EDUCATION DEPARTMENT STUDENTS' DESCRIPTIVE WRITING}

\author{
Nurwanti \\ Universitas Lakidende Unaaha \\ hakimnurwanti7@gmail.com
}

\begin{abstract}
This research analyzes the transitivity process by analyzing the third semester English Education Department students' descriptive writing at Lakidende Unaaha University. The objectives of the research are to find out the students' using of the transitivity process and to find out the most dominant of transitivity process in the descriptive writing. The subject of the research was nine students. The research applied descriptive qualitative method. The data was analyzed by Halliday's theory. In the research, it was found 153 clauses in the six transitivity processes. Material process got 25 times or $16.34 \%$, mental process obtained 25 times or $16.34 \%$, relational process was 91 times or $59.48 \%$, behavioral process occurred 8 times or $5.22 \%$, verbal process obtained 1 time or $0.65 \%$, and existential process was 3 times or $1.97 \%$. from the result of analyzing of the transitivity process of the third semester English Education Department students' descriptive writing at Lakidende Unaaha University, it can be conclude that, students uses six transitivity processes in writing descriptive text. The most dominat is relational process and the lowest is verbal process.
\end{abstract}

Keywords: Transitivity process, descriptive, writing

\section{INTRODUCTION}

Writing is one of English skills must mastered by students especially the candidate of English teacher. In mastering it, students must have ability in vocabulary, grammar, knowledge, the rules of writing a good paragraph, so forth, because it helps students to express well their opinion, thought, feeling, experience, arguments, so on. Nunan (1989: 36), writing is ann extremely complex cognitive activity in which the writer is required to mdemonstrate control of varieables simultaneously. At the sentence level, these include control of contents, format, sentence structure, vocabulary, spelling, and letter formation. Beyond the sentence, the writer must be able to structure and integrate information into cohesive and coherent paragraph and text. According to Rivers (1968), writing refers to the expression of ideas in a systematic way to organize the graphic conventions of the language. According to Sapkota (2013: 70), writing is the act of putting down the graphic symbols that present a language in order to convey the meaning so the reader can grasp the information which the writer has tried convey.

Descriptive text is one of kinds of writing text, it is a text that gives details to someone or something by describing and revealing. It uses five senses to describe human, animal, plant, view, voice, feel, emotion, taste, inanimate objects so on. Wishon and Burks (1980 : 379), descriptive writing reproduces the way things look, smell, taste, or sound; or it may also evoke moods, such as happiness, loneliness, or fear. In addition, According to Knapp 
and Watkins (2005 : 78), a description of place can include the physical and emotional description. Moreover, the description of place sometimes includes descriptions of objects or people that may be associated with the place. Wyrick (1987:81) states that the writer of description creates a word picture of persons, places, objects, and emotions using a careful selection of detail to make an impression on the reader.

From the explanation above about descriptive text, it is able to be inferred that descriptive text is a text to describe physic, mental, behavior, condition, and situation that can be expressed by using the ability of senses. The five senses help the content of descriptive text to be understood easily.

In writing a descriptive text, the writer must pay attention the grammatical structure while arranging the sentences. Using the inappropriate grammatical structure is making the writing meaningless. One part of grammatical that must be understood its using is transitivity. According to Hallyday (2004), transitivity is the meaning of clauses or sentence, which represents the pattern experience.

Halliday (2004) stated that transitivity is a grammatical system that expresses the world of experience into a number of types processes that can be arranged, the experience expressed a reflection of real reality as outlined in the text of writing. Martin et. al (1997: 102) describes transitivity as resource for construing our experience in terms of configuration of a process, participant, and circumstances. Thompson (1996: 78) states that transitivity refers to a system for describing the whole clause, rather than just the verb and its object.

Halliday (2004) classifies six different types of transitivity process, they are material process, mental process, relational process, behavioral process, verbal process, and existential process. The first is material process, it is involved physical action, like read, write, run, speak, etc. Halliday (1994: 110), material are processes are processes of doing. They express the notion that some entity "does" something-which may be done to some other entity. Material expression not only talks about body, physic, and material, but also it can be related to something abstract and occurring.

In material process, there are an actor and a goal. Actor is someone or something who doing an activity and goal is the purpose of the result of doing something. Halliday (2004), there are some verbs used in material process: give, send, buy, take, walk, and write. So, it can be conclude that verb used in the material process is a word which interprets a physical activity.

The second is mental process, Halliday (2004) states that mental process is a process of feeling, thinking, and perceiving. Halliday (2004) classifies mental process into three classes: cognition, it consists of thinking, knowing, and understanding, affection, consists of liking and fearing, and perception, consists of seeing and hearing. Based Halliday's (2004), mental process has two participants, they are senser, is a person or other participant (animal, plant, etc), and a phenomenon (which sensed). The verbs usually used in the mental process, like feel, hear, understand, see, so on. 


\section{Sibatile Jocurral}

Jurnal Ilmiah Bidang Sosial, Tkonomi, Budaya, Tekuologi, dan Pendidikan

The third is relational process. It can be said to be that of being, including having. The main characteristic of relational process is that they relate a participant to its identity and description. In essence, they state that something is/was/will be and hence relational process are often described as process of being. But other verbs may relate a participant to a description, for example seem, become, look, appear, etc (Marbun, 2017:9). Halliday (1994) stated that relational process come in two distinct modes, they are attributive, $a$ is an then attributive of $\mathrm{x}$, and identifying, $\mathrm{a}$ is the identifying of $\mathrm{x}$.

The fourth is behavioral process, according to Halliday (1994 : 139), behavioral processes are of (typically human) physiological and psychological behavior, like breathing, coughing, smiling, dreaming, and staring. It consists of the participant who behaves, called behaver, in the behavioral process, and circumstances (place, manner) and range.

The fifth is verbal process, it is the process saying and meaning (Halliday, 2004). According to Appendi and Mulyani (2020), there are four participants of verbal process, they are sayer (someone who says), receiver (the one whom saying is directed), verbiage (a name of verbalization itself), and target (entity targeted by the process of saying). It relates to direct and directs speech, so the verb used like say, ask, suggest, etc.

The sixth is existential process. It is about explain of existence of something or someone. It is known to use the words like there is, there are, so on.

In the research, the researcher was interested to investigate the transitivity process by analyzing the third semester English Education Department students' descriptive writing at Lakidende Unaaha University. The researcher wanted to know the transitivity process and the most dominant transitivity process in students' descriptive text.

\section{METHOD}

Descriptive qualitative was the method applied in the research. The researcher conducted the research in English Education Department at Lakidende Unaaha University. There were nine third semester students involved in the research. The third semester students were chosen because one of subjects learnt in the third semester was writing, especially writing the descriptive text. The data was obtained from the students' descriptive writing. The researcher gave 50 minutes to the students to write a descriptive text, the topic of the writing was to describe someone or something you love or like. The researcher asked the students to write just one paragraph.

To analyze the data, the researcher divided the students' descriptive writing paragraph into the sentences. Then, the researcher identified and classified the clauses based on the Halliday's six types of transitivity process (2004). After the analysis process was carried out, eventually the most dominant transitivity was obtained. 


\section{FINDINGS AND DISCUSSION}

\section{Findings}

The data was taken from the descriptive text written by nine third semester English Education Department students at Lakidende Unaaha University. The data were analyzed based on the process of transitivity. There are six processes in the transitivity analysis, those are material process, mental process, relational process, verbal process, behavioral process, and existential process. In the research, it was found and analyzed 153 clauses.

The distribution of transitivity analysis the students' descriptive writing can be seen below:

Table 1. The distribution of transitivity analysis the students' descriptive writing

\begin{tabular}{|l|c|c|c|c|c|c|}
\hline \multirow{2}{*}{ Respondents } & \multicolumn{7}{|c|}{ Processes } \\
\cline { 2 - 7 } & Material & Mental & Relational & Behavioral & Verbal & Existential \\
\hline Student 1 & 5 & 4 & 13 & 0 & 0 & 0 \\
\hline Student 2 & 6 & 5 & 11 & 2 & 1 & 1 \\
\hline Student 3 & 0 & 2 & 10 & 1 & 0 & 0 \\
\hline Student 4 & 4 & 2 & 13 & 1 & 0 & 0 \\
\hline Student 5 & 0 & 1 & 13 & 1 & 0 & 0 \\
\hline Student 6 & 2 & 1 & 6 & 0 & 0 & 0 \\
\hline Student 7 & 3 & 4 & 13 & 3 & 0 & 0 \\
\hline Student 8 & 1 & 2 & 5 & 0 & 0 & 2 \\
\hline Student 9 & 4 & 4 & 7 & 0 & 0 & 0 \\
\hline Total & 25 & 25 & 91 & 8 & 1 & 3 \\
\hline
\end{tabular}

From the distribution above, it can be known that the material process occurred 25 times, mental process had 25 times, relational process was 91 times, behavioral process got 8 times, verbal process occurred I time, and existential process was 3 times.

Table 2. Appearances of processes

\begin{tabular}{|c|c|c|}
\hline Processes & $\begin{array}{c}\text { Frequency of } \\
\text { Appearances }\end{array}$ & Percentages \\
\hline Material & 25 & $16.34 \%$ \\
\hline Mental & 25 & $16.34 \%$ \\
\hline Relational & 91 & $59.48 \%$ \\
\hline Behavioral & 8 & $5.22 \%$ \\
\hline Verbal & 1 & $0.65 \%$ \\
\hline Existential & 3 & $1.97 \%$ \\
\hline Total & 153 & $100 \%$ \\
\hline
\end{tabular}

The table above showed that relational process is the most dominant process found in the students' descriptive text. It had 91 clauses or $59.48 \%$. Then, material process and mental 


\section{Sibcatie gowreal}

Jurnal Ilmiah Bidang Sosial, Tkonomi, Budaya, Tekuologi, dan Pendidikan

E-ISSN: 2809-8544

process are in the second position. They got 25 clauses or $16.34 \%$. The third is behavioral process, it is about 8 clauses or $5.22 \%$. The fourth is existential process, it obtains 3 times. The last is verbal process, it only occurs 1 time.

\section{DISCUSSION}

This part is used to discuss the interpretation of the transitivity process obtained in the data. Based on the data calculation, there are six transitivity processes found, those are material process, mental process, relational process, behavioral process, verbal process, and existential process. The explanation about the six transitivity processes can be seen below:

The first is material process, there were 25 material transitivity found from all the data analyzed. Material process must have an action (process), an actor (participant) and goal, it is classified into three parts, and they are actor, process, and goal. In the research, it was found that in each sentence, it almost used actor and goal in active clause, and it has just one passive clause. It is obtained by student 1 ( 5 times), student 2 (6 times), student 4 (4 times), student 6 (2 times), student 7(3 times), student 8 (1 times), and student 9 (4 times). The following shows some clauses of descriptive text used material process:

\begin{tabular}{|c|c|c|}
\hline She (My mother) & Always fries & eggs \\
\hline Actor & Process : Material & Goal \\
\hline They (My cats) & Eat & Fish, chicken, and rice \\
\hline Actor & Process : Material & Goal \\
\hline $\mathrm{I}$ & Water & my red roses \\
\hline Actor & Process : Material & Goal \\
\hline $\mathrm{I}$ & was immediately kicked & by her (my cousin) \\
\hline Goal & Process : Material & Actor \\
\hline
\end{tabular}

The students used material process in their descriptive paragraph to explain the actor does or acts. It is the process of actor doing something, and something is done by an actor, called goal. In the research, the students can understand the function of actor and goal in their clauses, for instance, I water my red roses, the student give the function of $I$ as an actor, and make the actor to have a goal, it is my red roses, and of course water as a verb is used to express material process.

The second process is mental process, it relates to thought, feeling, and perception. In addition, perceiving in the mental process are seeing and hearing The happening is sensed like felt, thought, heard, and seen. Mental process consists of senser, process (cognition, affection, and perception), and phenomenon. In mental process, kinds of clauses usually used by students are mental affection and perception. It is obtained by student 1 (4 times), student 
2 (5 times), student 3 (2 times), student 4 (2 times), students 5 (1 times), student 6 (1 times), student 7(4 times), student 8 ( 2 times), and student 9 (4 times). The total of clauses identified as the mental process in students' descriptive writing are 23 . The following shows some clauses of descriptive text used mental process:

\begin{tabular}{|l|l|l|}
\hline I & Love & My Cats \\
\hline Senser & Process : Mental Affection & Phenomenon \\
\hline
\end{tabular}

\begin{tabular}{|l|c|c|}
\hline I & sometimes see & several butterflies and bees \\
\hline Senser & Process : Mental Perception & Phenomenon \\
\hline
\end{tabular}

\begin{tabular}{|l|c|c|}
\hline I & really admire & him (Ki Hajar Dewantara $)$ \\
\hline Senser & Process: Mental Affection & Phenomenon \\
\hline
\end{tabular}

The students used mental process in their descriptive paragraph to describe what someone (senser) thought, feel, and perceive about a thing / a person. Someone who thinks, feels, and perceives, called senser. What a senser thinks, feels, and perceives namely mental process. The thing is thought, felt, and perceived, it can be said as phenomenon. In the research, the students can understand how to use the mental process in clauses, for example, I love my cats, I is as a senser, love is as mental affection process (feeling), and my cats is considered as a phenomenon.

The third is relational process, researcher found 91 clauses from the data. In the relational process, it is divided into three parts, those are carrier, attributive (intensive, possessive, and circumstantial), and attribute. In the case, mental process occurred to student 1 (13 times), student 2 (11 times), student 3 (10 times), student 4 (13 times), student 5 (13 times), student 6 (6 times), student 7 (13 times), students 8 (5 times), and student 9 (7 times). The following shows some clauses of descriptive text used relational process:

\begin{tabular}{|c|c|c|}
\hline His voice (Jarjit) & Sounds & Adult \\
\hline Carrier & Attributive : Circumstantial & Attribute \\
\hline She (my cousin) & Has & white skin \\
\hline Carrier & Attributive : Possessive & Attribute \\
\hline He (Jungkook) & Has & a small mole \\
\hline Carrier & Attributive : Possessive & Attribute \\
\hline
\end{tabular}

The students used relational process in their descriptive writing to explain and identify (identifying) what they described. Also the relational process uses to give a quality to something (attributing). For instance, she (my cousin) has white skin. The student try to 


\section{Sibcitie gourral}

Jurnal Ilmiah Bidang Sosial, Thonomi, Budaya, Tekuologi, dan Pendidikan

E-ISSN: 2809-8544

identify and attribute someone described, she (carrier), has is attributed as possessive, and white skin is an attribute

The fourth is behavioral process, it relates to physiological process. It is between material process and mental process. Behavioral process consist of behaver, process (behavioral), circumstances (place, manner, and range). In the research, it occurred 8 times, student 2 (2 times), student 3 (1 times), student 4 (1 times), student 5 (1 times), and student 7 (3 times). The following shows some clauses of descriptive text used behavioral process:

\begin{tabular}{|c|l|l|}
\hline She $($ My cousin $)$ & Goes & Shopping \\
\hline Behaver & Process : Behavioral & Circumstances : range \\
\hline
\end{tabular}

\begin{tabular}{|c|c|l|}
\hline Upin and Ipin & Live & in the beautiful village \\
\hline Behaver & Process : Behavioral & Circumstances : Place \\
\hline
\end{tabular}

\begin{tabular}{|c|l|c|}
\hline She $($ my cousin $)$ & Speaks & Politely \\
\hline Behaver & Process : Behavioral & Circumstances : Manner \\
\hline
\end{tabular}

Students used in their descriptive writing to explain body movement, psychological process, and place. For example, she (my cousin) speaks politely. The word she is a behaver, speaks is a behavioral process, and politely is an adverb to express the circumstances of manner.

Verbal process is the process of reporting, quoting, and projecting. In the other words, verbal process is saying and meaning process that related to the information delivered. Verbal process consists of sayer, reporting/quoting/projecting, and reported/quoted/projected. In the research, there was only one student used verbal process, the student 2 (1 time). It is the lowest intransitivity process done by students. The following shows a clause of descriptive text used verbal process:

\begin{tabular}{|l|l|c|}
\hline I & Ask & them (my cats $)$ \\
\hline Sayer & Process: Verbal & Reported \\
\cline { 1 - 2 } & Reporting & \\
\hline
\end{tabular}

The sentence in the verbal process used by student was reporting and reported, it is about saying something by asking the object to do something. The sentence "I ask them (my cats), in which $I$ has a function as sayer, ask is verbal (reporting), and them (reported).

The last process is existential process, it is identified as intransitivity which explaining the existence of something. In the existential process, students used three times. There was student 2 (1 time) and student 8 (3 times). It can be seen below the example clauses by using the existential process.

\begin{tabular}{|l|l|l|}
\hline There & Are & three cats \\
\hline & Process : Existential & Existent \\
\hline
\end{tabular}




\begin{tabular}{|l|l|l|}
\hline There & Are & Several sizes of meatball \\
\hline \multicolumn{3}{|c|}{ Process : Existential } \\
\hline There & Are & $\begin{array}{l}\text { two kinds of meatball surface } \\
\text { texture }\end{array}$ \\
\hline & Process : Existential & \multicolumn{1}{c|}{ Existent } \\
\hline
\end{tabular}

In the research students used the existential process to explain the existence of something. To explain existence, it uses there and to be (past/present/future). In this case, the clause just uses there and to be in the singular present tense form. For instance, There are two kinds of meatball surface texture, there are shows existential process, and two kinds of meatball surface texture is identified as existent.

From discussion of the research above, it can be inferred that the most dominant transitivity process is relational process. All students used it to write the descriptive text, it is in accordance with its function, it is describing, attributing, and identifying. The second is material and mental process, the material process has a function to describe an activity or a doing done by doer, and the mental process is a transitivity involving feeling, thinking, and perception, in which these three kinds are used to describe an object in the descriptive text. The third is behavioral process, it is used to describe an object in the psychological way. The fourth position is the existential process, a transitivity process which tells about the existence of something. So, it is bale to be stated that these five mental processes are really needed in writing a descriptive text. It is in line with Wishon and Burks (1980), descriptive writing reproduces the way things look, smell, taste, or sound; or it may also evoke moods, such as happiness, loneliness, or fear. In addition, Knapp \& Watkins (2005), descriptive text consists of identification and description is a process on how to describe the object. Descriptive is a sort of text used by every writer or a person to explain a thing, individual, animal, location, or incident to a reader or listener. Whereas, the lowest transitivity process used by students in writing the descriptive text is verbal process, it intends to direct and indirect speech, writing the descriptive text seldom uses direct and indirect speech.

\section{CONCLUSION}

In the research, it was found 153 clauses in the six transitivity processes. Material process got 25 times or $16.34 \%$, mental process obtained 25 times or $16.34 \%$, relational process was 91 times or $59.48 \%$, behavioral process occurred 8 times or $5.22 \%$, verbal process obtained 1 time or $0.65 \%$, and existential process was 3 times or $1.97 \%$. from the result of analyzing of the transitivity process of the third semester English Education Department students' descriptive writing at Lakidende Unaaha University, it can be conclude that, students uses six transitivity processes in writing descriptive text. The most dominat is relational process and the lowest is verbal process. 


\section{Sibaitie Jourral}

Jurnal Ilmiah Bidang Sosial, Thonomi, Budaya, Tekuologi, dan Pendidikan

E-ISSN8 2809-8544

\section{REFERENCES}

Apendi, Tia Listiana \& Mulyani, Euis Rina. (2020). The Analysis of Transitivity Process of Students' Descriptive Text. Journal of Project. https://journal.ikipsiliwangi.ac.id/index.php/project/article/view/3957

Halliday, M.A.K (1994). An Introduction to Functional (2 $\left.{ }^{\text {nd }} . e d\right)$. London: Edward Arnold.

Halliday, M.A.K \& Matthiesen, C.M.I.M. (2004). An Introduction to Functional Grammar. London: Arnold. https://doi.org/10.4324/9780203783771.

Knapp, P., \& Watkins, M. (2005). Genre, Text, Grammar. Sdyney: University of New South Wales Press Ltd.

Marbun. Lydia April Yanti. (2017). Process Types of Transitivity System in the National Graphic's Article. https://www.semanticscholar.org/paper/Process-Types-ofTransitivity-System-in-the-MarbunYanti/8604b432dca3feafaf8754ed107c37333768c1d1.

Martin, J.R.et.al. (1997). Working with Functional Grammar. London: Arnold

Nunan, D. (1989). Understanding Language Classroom. UK. Prentice Hall.

Rivers, W. (1968). Teaching Foreign Language Skill. Chicago: Chicago University.

Sapkota, Ashok. 2013. Developing Students' writing Skill through Peer and Teacher Correction : An Action Research. Journal of NELTA. https://www.researchgate.net/publication/314541841_Developing_Students'_Writing Skill_through_Peer_and_Teacher_Correction_An_Action_Research.

Thompson, Geoff (1996). Introducing Functional Grammar. China. Edward Arnold (Publishers) Ltd.

Wishon, G. E., and Burks, J. M. (1980). Let's Write English. New York: American Book Company.

Wyrick, Jean. (1987). Steps to Writing Well. New York: Rinehart and Winston. Inc. 
PENDIDIKAN AGAMA ISLAM DI PERGURUAN TINGGI UMUM:

LANDASAN DASAR, KONSEP, DAN APLIKASI

Mukhtar Zaini Dahlan, S.Pd.I., M.Pd.I.

DOI: https://doi.org/10.54443/sibatik.v2i1.11 